\title{
Connectivity between the Algerian population of Greater Flamingo Phoenicopterus roseus and those of the Mediterranean basin
}

\author{
Abdennour Boucheker1,2,3, Boudjéma Samraoui ${ }^{3}$, Roger Prodon², Juan A Amat ${ }^{4}$, Manuel Rendón-Martos 5 , \\ Nicola Baccetti ${ }^{6}$, Francesc Vidal i Esquerre ${ }^{7}$, Sergio Nissardi ${ }^{8}$, Özge Balkız ${ }^{9}$, Christophe Germain ${ }^{1}$, \\ Mouloud Boulkhssaim ${ }^{10}$ and Arnaud Béchet ${ }^{1^{*}}$ \\ ${ }^{1}$ Centre de recherche de la Tour du Valat, Le Sambuc, 13200 Arles, France \\ ${ }^{2}$ CEFE-CNRS, 1919 Route de Mende, 34293, Montpellier, France \\ ${ }^{3}$ Laboratoire de recherche et de conservation des zones humides, University of Guelma, Algeria, and Center of Excellence for Research in \\ Biodiversity, King Saud University, Riyadh, Saudi Arabia \\ ${ }^{4}$ Estación Biológica de Doñana, Consejo Superior de Investigaciones Científicas, Apartado 1056, 41080 Sevilla, Spain \\ ${ }^{5}$ Reserva Naturel Laguna de Fuente de Piedra, Consejeria de Medio Ambiente, Apartado 1, 29520 Fuente de Piedra (Málaga), Spain \\ ${ }^{6}$ Istituto Superiore Protezione e Ricerca Ambientale, via ca' Fornacetta, 9 I-40064 Ozzano Emilia BO, Italy \\ 7 Àrea de Protecció i Recerca, Parc Natural del Delta de l'Ebre, Av. Catalunya, 4643580 - Deltebre, Spain \\ ${ }^{8}$ Anthus, s. n. c., via L. Canepa 3, 09129 Cagliari, Italy \\ ${ }^{9}$ Doğa Koruma Merkezi, Ortadoğu Sitesi 1589, Sokak no. 4, Yüzüncüyıl, Ankara, Turkey \\ ${ }^{10}$ Institut de Biologie, Université d'Oum El Bouaghi, Algeria \\ *Corresponding author, e-mail: bechet@tourduvalat.org
}

In the Mediterranean basin, Greater Flamingos Phoenicopterus roseus constitute a metapopulation with natal and breeding dispersal among colonies. However, the rate of exchange between European and North African colonies remains poorly known. In this paper, we document the wintering and breeding of European flamingos in Algeria and provide the first post-fledging dispersal data for flamingos born in Algeria. At breeding colonies in Algeria, most ringed birds (99.4\% of 835 birds) originated from north-western Mediterranean colonies (397 individuals born in France, 369 in Spain, 57 in Sardinia and seven in continental Italy), but there were also four from Turkey (the first evidence of natal dispersal from a north-eastern Mediterranean colony to Algeria) and one from Algeria. Among the 860 fledglings ringed in Algeria in 2006 and 2009, 619 different individuals were resighted from August 2006 to September 2010 in a total of 980 resightings. A large proportion (73\%) of these birds was observed at North African sites, while the remaining ones reached both north-western (168 birds) and north-eastern (three birds) Mediterranean wetlands, suggesting extensive interchange between colonies from both sides of the Mediterranean Sea.

\section{Introduction}

The Greater Flamingo Phoenicopterus roseus is a partially migratory, dispersing and nomadic species (Johnson and Cézilly 2007). The world population is estimated at $>500000$ individuals (Wetlands International 2006). About $60 \%$ of the Greater Flamingo population is located in the Mediterranean region (Childress 2005, Wetlands International 2006). With the exception of a few managed sites in the northern part of the Mediterranean region, successful breeding of the Greater Flamingo occurs irregularly and depends on rainfall (McCulloch and Irvine 2004, Johnson and Cézilly 2007). Ringed Greater Flamingos born in France, Spain and Italy have been observed to breed at other colonies in the Mediterranean and in West Africa, often moving to a third colony thereafter (Balkız et al. 2007, Diawara et al. 2007, Balkız et al. 2010). It has been suggested that the Mediterranean colonies could function as a metapopulation (Balkız et al. 2010). Following sustained conservation effort undertaken at the two most important breeding colonies in the western Mediterranean (Camargue [Fangassier] in France and Fuente de Piedra in Spain), the Greater
Flamingo successfully expanded its range in southern Europe, and in North and West Africa (Nager et al. 1996, Samraoui et al. 2006, Diawara et al. 2007, Johnson and Cézilly 2007, Baccetti et al. 2008).

Movements between southern Europe and North Africa have long been known (Johnson and Cézilly 2007), and North Africa has generally been considered to be an important wintering ground for Greater Flamingos and a 'nursery' for immature flamingos from Europe (Smart et al. 2009). However, the possibility of breeding exchanges between European breeding colonies and North African breeding colonies, despite their potential importance for the viability of the flamingo metapopulation (Hanski and Gilpin 1997), has only recently been documented (Khelifa et al. 2009, Samraoui et al. 2009). Breeding occurs irregularly in North Africa, generally following wet winters (Samraoui et al. 2006, 2010).

A survey of the wetlands complex of the Hauts Plateaux in Algeria, initiated in 2002, revealed that the region is an important wintering and breeding site for waterbirds 
(Boulkhssaïm et al. 2006, Samraoui et al. 2006, Samraoui and Samraoui 2008). The survey also discovered the first recorded breeding colony of Greater Flamingos in Algeria, at Garaet Ezzemoul (Samraoui et al. 2006) (Figure 1). A second colony was subsequently discovered at El Goléa in the northern part of the Algerian Sahara in 2009 (Bouzid et al. 2009). Breeding failed twice at Garaet Ezzemoul, in 2003 and 2004, because of illegal hunting and egg pilfering (Saheb et al. 2006), but subsequent protection of the breeding colony by hired wardens enabled successful breeding in 2005, 2006 and 2009 at Garaet Ezzemoul and in 2009 at El Goléa. This successful breeding enabled ringing of Algerian-born chicks in 2006 and 2009.

The main objectives of this paper are: (1) to reassess current knowledge of the North African range of the Mediterranean metapopulation of the Greater Flamingo, (2) to clarify the role of Algeria in the population dynamics of breeders from eastern and western Mediterranean colonies, (3) to investigate movements from east Mediterranean colonies to Algeria, and (4) to map the post-fledging and breeding dispersal of flamingos born in Algeria.

\section{Methods}

\section{Study area}

The largest Greater Flamingo breeding colony in Algeria is located in the eastern part of the Haut Plateaux at Garaet Ezzemoul $\left(35^{\circ} 53.137^{\prime} \mathrm{N}, 06^{\circ} 30.200^{\prime} \mathrm{E}\right)$, in the Wilaya of Oum El-Bouaghi. It is located $110 \mathrm{~km}$ from the coast at an altitude of $900 \mathrm{~m}$. This temporary shallow lake has a surface area of 6000 ha, with water depth rarely exceeding $0.5 \mathrm{~m}$ (Samraoui et al. 2006). Greater Flamingos breed on the only natural islet of Ezzemoul, situated in the northern sector of the lake about $1 \mathrm{~km}$ from the northern shore. The second Algerian colony is also located within a salt lake, at El Goléa $\left(30^{\circ} 31.778^{\prime} \mathrm{N}, 2^{\circ} 56.201^{\prime} \mathrm{E}\right)$, in the middle of the Algerian Sahara, $780 \mathrm{~km}$ south of the Mediterranean coast at an altitude of $379 \mathrm{~m}$. The site consists of two basins: an upper basin with brackish water mixed with sewage and irrigation waters from the oasis of El Goléa, and a lower basin with saline water and devoid of vegetation (Khelifa et al. 2009).

\section{Number of north Mediterranean Greater Flamingos wintering at Algerian sites}

Resighting records of ringed Greater Flamingos during the non-breeding season in Algeria (November to January) were extracted from the Greater Flamingo database managed by the Centre de Recherche de la Tour du Valat (http://www.flamingoatlas.org), or recorded during fieldwork conducted by members of the Laboratoire de recherche des zones humides (Algeria). Data include all the ringed birds resighted at least once in Algeria for six non-breeding seasons (2004/05 to 2009/10), during which the number of observers varied from $2-5$ in $2004 / 05,1-2$ in 2005/06, $2007 / 08$ and 2008/09, $1-4$ in 2006/07 and 1-3 in 2009/10. The numbers of days of observations for the sampled splityears were nine, five, 23, 14, 12 and six, respectively.

\section{Resightings of ringed birds at the colonies}

Fieldwork was conducted between March and September in 2005 and 2006 at Garaet Ezzemoul, and in the same months in 2009 at both Garaet Ezzemoul and El Goléa. Once hatching was under way, resightings of ringed flamingos were carried out using a telescope from a mobile hide at a distance of about $40 \mathrm{~m}$ from the breeding islet. At Garaet Ezzemoul, observations were performed at least twice a week in 2005, 3-5 d per week in 2006 and daily in 2009. At El Goléa in 2009 observations were made on 5-6 d per week. During the three seasons, totals of 92 and $17 \mathrm{~d}$, amounting to $276 \mathrm{~h}$ and $51 \mathrm{~h}$, were spent conducting observations at the Garaet Ezzemoul and El Goléa colonies, respectively. A bird was considered to be a breeder if it was observed incubating an egg, attending a chick or at the same nest for more than $24 \mathrm{~h}$. Nests were identified from each other using background landscape features (Balkız et al. 2007). At the end of each breeding season, numbers of nests were counted to estimate the minimum size of the breeding population.

\section{Estimating numbers of north Mediterranean Greater Flamingos breeding at Algerian colonies}

In order to estimate the proportions of breeders at Algerian colonies born to the north of the Mediterranean Sea, we used the approach of Balkız et al. (2007). The number of ringed flamingos from European colonies that were confirmed as breeders at Algerian colonies represent only a proportion of the total number of such breeders that might move to Algerian colonies because: (1) in colonies where ringing was carried out, not all chicks were ringed, so that unringed birds from the European colonies may have bred at the Algerian colonies; and (2) the probability of resighting ringed breeders was less than one due to field conditions and limited observer effort. Given that PVC ring loss is rare in flamingos (Johnson and Cézilly 2007), we assumed that it did not influence the number of ringed breeders observed in Algeria. Thus, to estimate the number of dispersing birds breeding at Algerian colonies we first calculated the average proportion of ringed chicks (out of the total number of fledglings) in the Camargue since 1977, in Fuente de Piedra since 1986, in Cagliari (Sardinia) since 1997, in Comacchio since 2000, in Doñana in 2003, in the Ebro delta since 2004 and in the Gediz delta since 2003. Because birds commence breeding from an age of three years (Johnson and Cézilly 2007) we set the limit of the last ringing year to be three years before the year of observation at the Algerian colonies (up to 2002 for 2005, 2003 for 2006 and 2006 for 2009). We used the resighting histories of ringed flamingos recorded as confirmed breeders at Algerian colonies during the 2005, 2006 and 2009 breeding surveys to estimate the daily resighting probability of ringed birds $\left(P_{\text {daily }}\right)$ as:

$$
P_{\text {daily }} \frac{n}{i \mathrm{u}(d-1)}
$$

where $n$ is the number of resightings following the first observation summed over all individuals, $i$ is the number of different individuals observed, and $d$ is the number of days of observations during the survey $(d-1$ is thus the maximum possible number of resightings for each individual). We then calculated the probability of recording a ringed bird present in an area during the whole breeding season $\left(P_{\text {season }}\right)$ as: 


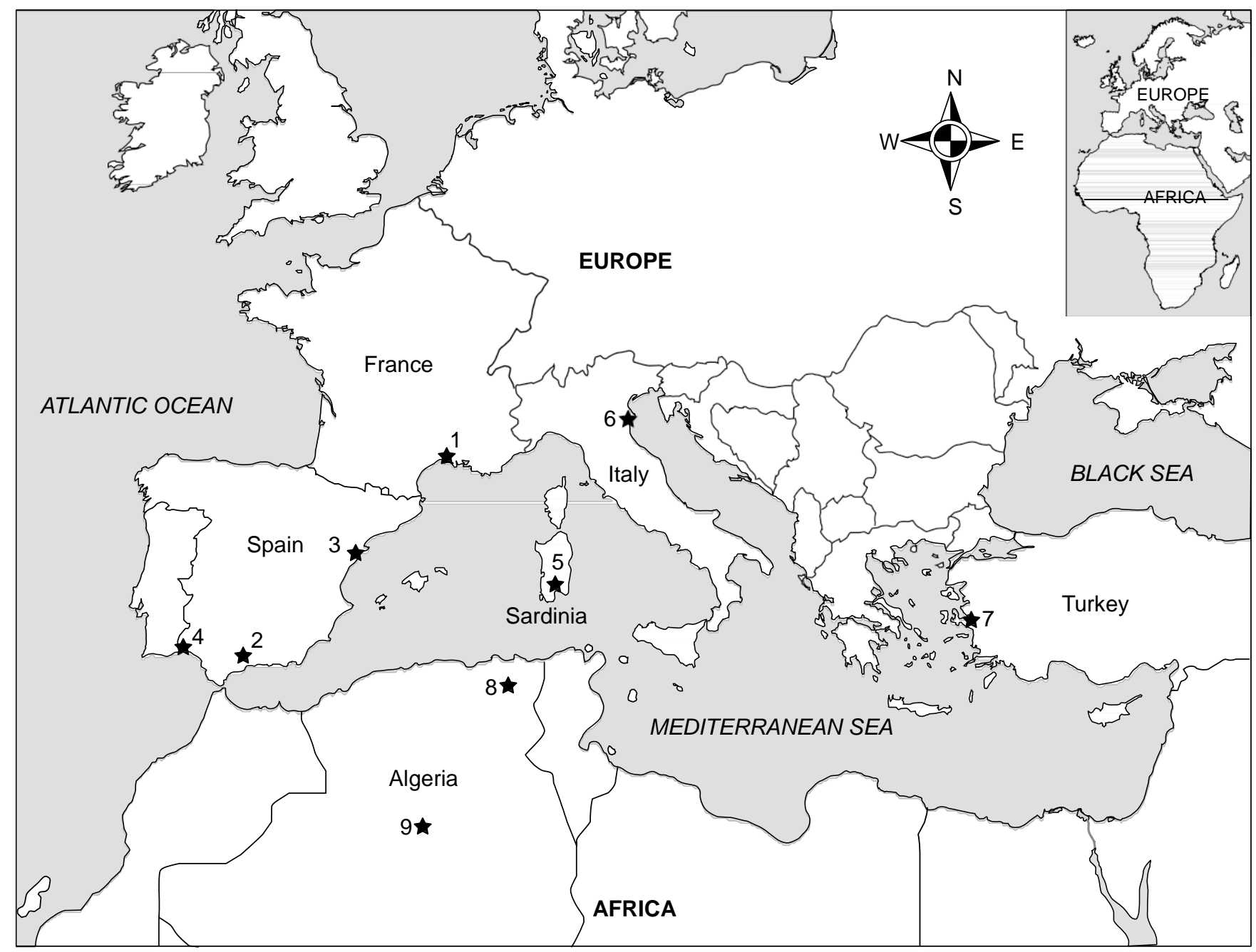

Figure 1: Location of Greater Flamingo breeding sites in the Mediterranean basin. 1, Camargue; 2, Fuente de Piedra; 3, Ebro delta; 4, Odiel Marshes, Doñana; 5, Cagliari, Sardinia; 6, Comacchio; 7, Camalti; 8, Garaet Ezzemoul; 9, El Goléa

$$
P_{\text {season }} \quad 1-\left(1-P_{\text {daily }}\right)^{d} \text {. }
$$

\section{Age structure of north-western Mediterranean flamingos breeding at Garaet Ezzemoul}

In the north-western Mediterranean region, Greater Flamingos regularly breed in the Camargue and at Fuente de Piedra, two long-established colonies (Cézilly and Johnson 1995, Cézilly et al. 1996, Nager et al. 1996, Johnson 1997, Pradel et al. 1997). We compared the age structure of ringed birds originating from the Camargue or from Fuente de Piedra that were observed breeding at Garaet Ezzemoul with that of ringed birds breeding in the Camargue and at Fuente de Piedra. Greater Flamingos reach sexual maturity several years after fledging and usually begin to breed when they are three years old, but the recruitment is often delayed (Cézilly et al. 1996, Pradel et al. 1997, Tavecchia et al. 2001), either due to environmental constraints or as an individual strategy (Nager et al. 1996, Pradel et al. 1997, Tavecchia et al. 2001). Full recruitment of Greater Flamingos to breeding populations is believed to be achieved by the age of 10 years (Pradel et al. 1997). This implies that individuals older than nine years observed breeding for the first time are likely previously to have bred elsewhere or to have been unnoticed breeders at the same colony (Green et al. 1989, Nager et al.1996, Balkız et al. 2007). For these reasons, we chose our first age-class as individuals aged between age three and nine years and our second age class as individuals 10 years old or older. After pooling the two age-classes for the breeders of 2006 and 2009, we compared the age structures using a $\chi^{2}$ test. In 2009, data on French Greater Flamingos at Fuente de Piedra were unavailable.

\section{Ringing in Algerian colonies}

Totals of 208 and 638 chicks were ringed at Garaet Ezzemoul on 11 August 2006 and 31 July 2009, respectively. Eight flamingo chicks were ringed on 17 June 2009 at the El Goléa colony. All chicks were ringed with a PVC ring bearing a unique alphanumeric code (Johnson and Cézilly 2007). The resightings and recoveries of these individuals from August 2006 to September 2010 enabled the mapping of post-fledging dispersal of Greater Flamingos born in Algeria. We calculated the farthest resighting of individuals 
from their natal colony assuming movements took place in a straight line (Amat et al. 2005).

\section{Results}

Origin and age-structure of north Mediterranean flamingos wintering at Algerian sites

We recorded 976 resightings of 384 different individuals wintering in Algeria. Among them, 171 (44.5\%) were born in France, 146 (38.0\%) in Spain, 44 (11.5\%) in Sardinia,
$15(3.9 \%)$ in continental Italy, six (1.6\%) in Algeria and two $(0.5 \%)$ in Turkey. Most rings $(98.9 \%)$ were read in the eastern part of Algeria (Hauts Plateaux and the northeastern part of the Algerian Sahara), 1\% were read in the north-centre of Algeria (Réghaia Lake and Boughzoul Dam), and only $0.1 \%$ were read in north-western Algeria (Petit Lac d'Oran). The age structure of these flamingos showed predominance of juvenile and young individuals, but with a clear trend towards older individuals wintering in Algeria in recent years (Figure 2).

Table 1: Daily and seasonal probabilities of resighting ringed birds and estimates of the number of Greater Flamingos from colonies to the north of the Mediterranean Sea that bred in Algeria, at Garaet Ezzemoul in 2005, 2006 and 2009 and at El Goléa in 2009

\begin{tabular}{|c|c|c|c|c|c|}
\hline \multirow{2}{*}{ Country } & \multirow{2}{*}{ Breeding site } & \multicolumn{3}{|c|}{ Garaet Ezzemoul } & \multirow{2}{*}{$\begin{array}{c}\text { El Goléa } \\
2009\end{array}$} \\
\hline & & 2005 & 2006 & 2009 & \\
\hline \multicolumn{2}{|c|}{ Daily resighting probability $\left(P_{\text {daily }}\right)$} & 0.064 & 0.018 & 0.012 & 0.099 \\
\hline \multicolumn{2}{|c|}{ Resighting probability for the field season $\left(P_{\text {season }}\right)$} & 0.232 & 0.310 & 0.449 & 0.862 \\
\hline \multicolumn{6}{|c|}{ Number and origin of ringed birds observed breeding at Algerian colonies } \\
\hline France & Camargue & 17 & 92 & 296 & 3 \\
\hline \multirow[t]{3}{*}{ Spain } & Fuente de Piedra & 9 & 139 & 222 & 1 \\
\hline & Ebro Delta & 0 & 0 & 6 & 1 \\
\hline & Doñana & 0 & 0 & 10 & 1 \\
\hline \multirow[t]{2}{*}{ Italy } & Sardinia & 0 & 9 & 50 & 5 \\
\hline & Comacchio & 0 & 3 & 4 & 0 \\
\hline Algeria & Ezzemoul & 0 & 0 & 1 & 3 \\
\hline Turkey & Gediz delta & 0 & 0 & 4 & 0 \\
\hline Total & & 26 & 243 & 593 & 14 \\
\hline
\end{tabular}

Number of ringed birds from colonies north of the Mediterranean Sea and in Algeria estimated to be breeding at Algerian colonies

$\begin{array}{llrrrr}\text { France } & \text { Camargue } & 157 & 837 & 2674 & 27 \\ \text { Spain } & \text { Fuente de Piedra } & 96 & 1457 & 2410 & 11 \\ & \text { Ebro Delta } & 0 & 0 & 14 & 2 \\ & \text { Doñana } & 0 & 0 & 156 & 16 \\ \text { Italy } & \text { Sardinia } & 0 & 138 & 730 & 73 \\ & \text { Comacchio } & 0 & 5 & 6 & 0 \\ \text { Algeria } & \text { Ezzemoul } & 0 & 0 & 18 & 54 \\ \text { Turkey } & \text { Gediz delta } & 0 & 0 & 97 & 0 \\ \text { Total } & & 253 & 2437 & 6105 & 183\end{array}$

Proportion of fledgings at colonies north of the Mediterranean Sea and in Algeria that were ringed up to three years prior to resightings at Algerian colonies

$\begin{array}{llllll}\text { France } & \text { Camargue } & 0.108 & 0.109 & 0.110 & 0.110 \\ \text { Spain } & \text { Fuente de Piedra } & 0.093 & 0.095 & 0.092 & 0.092 \\ & \text { Ebro Delta } & 0 & 0 & 0.427 & 0.427 \\ & \text { Doñana } & 0 & 0 & 0.064 & 0.064 \\ \text { Italy } & \text { Sardinia } & 0 & 0.065 & 0.068 & 0.068 \\ & \text { Comacchio } & 0 & 0.649 & 0.660 & 0 \\ \text { Algeria } & \text { Ezzemoul } & 0 & 0 & 0.055 & 0.055 \\ \text { Turkey } & \text { Gediz delta } & 0 & 0 & 0.041 & 0 \\ \text { Total } & & 0.201 & 0.919 & 1.520 & 0.818\end{array}$

Number of birds from colonies to the north of the Mediterranean Sea or in Algeria estimated to be breeding at Algerian colonies

\begin{tabular}{|c|c|c|c|c|c|}
\hline France & Camargue & 677 & 2700 & 5948 & 31 \\
\hline \multirow[t]{3}{*}{ Spain } & Fuente de Piedra & 414 & 4700 & 5360 & 13 \\
\hline & Ebro Delta & 0 & 0 & 31 & 2 \\
\hline & Doñana & 0 & 0 & 347 & 19 \\
\hline \multirow[t]{2}{*}{ Italy } & Sardinia & 0 & 445 & 1624 & 84 \\
\hline & Comacchio & 0 & 16 & 13 & 0 \\
\hline Algeria & Ezzemoul & 0 & 0 & 40 & 63 \\
\hline Turkey & Gediz delta & 0 & 0 & 216 & 0 \\
\hline Total & & 1091 & 7861 & 13579 & 212 \\
\hline Percent & ding birds & 10 & 87 & 112 & 151 \\
\hline
\end{tabular}




\section{Breeding dispersal from the north of the Mediterranean to Algerian colonies}

A total of 11120 resightings of ringed individuals was made during the three breeding seasons at Garaet Ezzemoul (2005, 2006 and 2009), confirming the breeding of 835 ringed individuals. Most birds (99.4\%) originated from north-western Mediterranean colonies (397 individuals born in France, 369 in Spain, 57 in Sardinia and seven in continental Italy). We also confirmed breeding by four flamingos born in Turkey and one born in Algeria.

At El Goléa in 2009, 348 resightings confirmed the breeding of 11 individuals from north-western Mediterranean colonies (three born in France, three in Spain and five in Sardinia). We also recorded the breeding by three birds born in Algeria.

In the Camargue, from 1977 to 2002, 10.8\% of 165372 fledged chicks were ringed. The resightings in 2005 of 17 ringed breeders in Algeria from the Camargue could therefore correspond to the presence of as many as 157 breeders (17/0.108) from France at the Garaet Ezzemoul colony (Table 1). In 2005 at the Garaet Ezzemoul colony, the estimated daily resighting probability $\left(P_{\text {daily }}\right)$ was 0.064 and the probability of observing a ringed bird during the whole study period $\left(P_{\text {season }}\right)$ was 0.232 . We thus estimate that 677 breeders (157/0.232) from France were actually breeding at Ezzemoul in 2005 (Table 1). Following the same reasoning, we estimated that numbers of breeders at Garaet Ezzemoul in 2005, 2006 and 2009, which were hatched at colonies north of the Mediterranean Sea, were 1 091, 7861 and 13 539, respectively (Table 1). At El Goléa in 2009, 149 breeders were estimated to have hatched at colonies north of the Mediterranean Sea. At the end of these breeding seasons, 5 379, 4509 and 6060 nests were counted at Garaet Ezzemoul and 70 nests at El Goléa, respectively.

Resightings of ringed flamingos indicate that young breeders (aged nine years or less) from north-western Mediterranean colonies were more abundant at Garaet Ezzemoul than at the Fuente de Piedra and Camargue colonies in both 2006 and 2009 (Figure 3). The differences

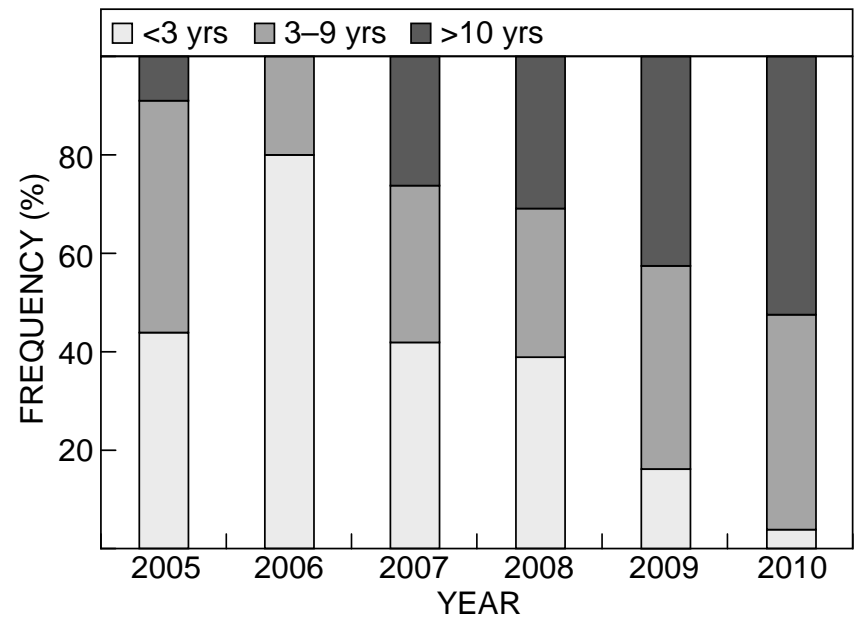

Figure 2: Age structure of Greater Flamingos born at colonies north of the Mediterranean Sea that wintered at Algerian wetlands from 2005 to 2010 were significant: breeding flamingos from the northwestern Mediterranean colonies were younger at Garaet Ezzemoul than at the other two colonies during both years $\left(\chi_{2006}^{2}=195.5, \mathrm{df}=2, P<0.0001 ;\right.$ and $\chi_{2009}^{2}=208.7$, $\mathrm{df}=2, P<0.0001)$. However, older breeders from the north-western Mediterranean colonies were also observed at Garaet Ezzemoul.

\section{Postfledging dispersal of flamingos born in Algeria}

Among the 860 flamingos ringed as chicks in Algeria in 2006 and 2009, 619 different individuals were resighted from August 2006 to September 2010, for a total of 980 resightings made outside the Algerian colonies (Figure 4). Of these, $73 \%$ of the individuals were resighted in North Africa (Algeria 292 individuals, Tunisia 132, Morocco 12 and Libya 12), whereas $27 \%$ were resighted in north-western Mediterranean countries (Spain 61 individuals, Italy 67 , France 31 and Portugal nine) and $<1 \%$ were resighted in Turkey (three individuals, Table 2).

\section{Discussion}

Until recently, Algerian wetlands were confined to the role of wintering grounds for immature Greater Flamingos, or of stop-over places for both immature and adult flamingos during long-range movements between large wetland complexes (Ledant et al. 1981, Isenmann and Moali 2000, Amat et al. 2005). Research has now highlighted the importance of Algerian wetlands as wintering, moulting and breeding sites for Greater Flamingos and other waterbirds (Boulkhssaïm et al. 2006, Saheb et al. 2006, Samraoui et al. 2006, Samraoui and Samraoui 2008). However, until this study, no data on the age structure and origin of the Greater Flamingos present in Algeria were available.

Our results suggest a trend toward an increasing number of older Greater Flamingos wintering in Algeria. Up until 2006, most Greater Flamingos wintering in Algeria were less than 10 years old. The reason for the increased winter usage

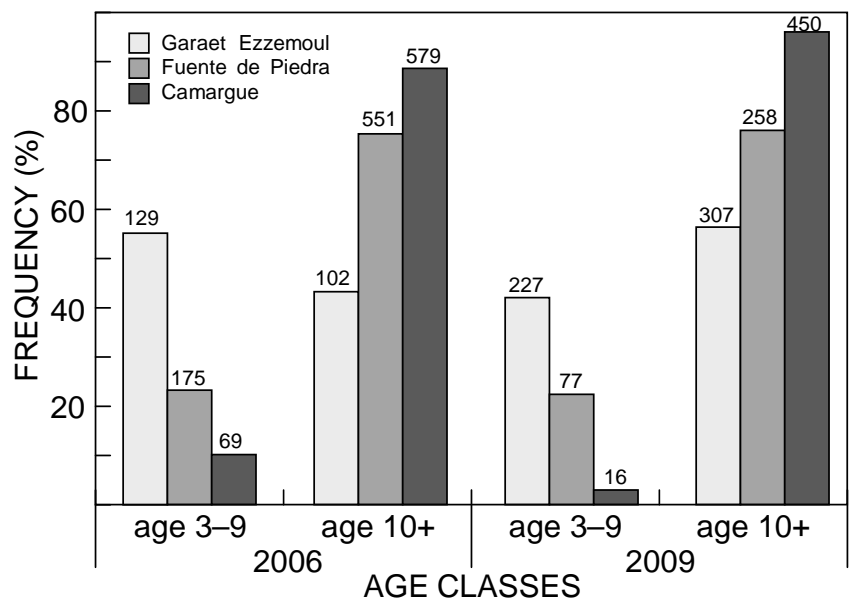

Figure 3: Age structure of Greater Flamingos born at two large colonies to the north of the Mediterranean Sea (Camargue in France and Fuente de Piedra in Spain) that bred at those colonies and at Garaet Ezzemoul in 2006 and 2009. In 2009, data on breeding of French birds at Fuente de Piedra was unavailable. The number of breeders observed at colonies is shown in parentheses 


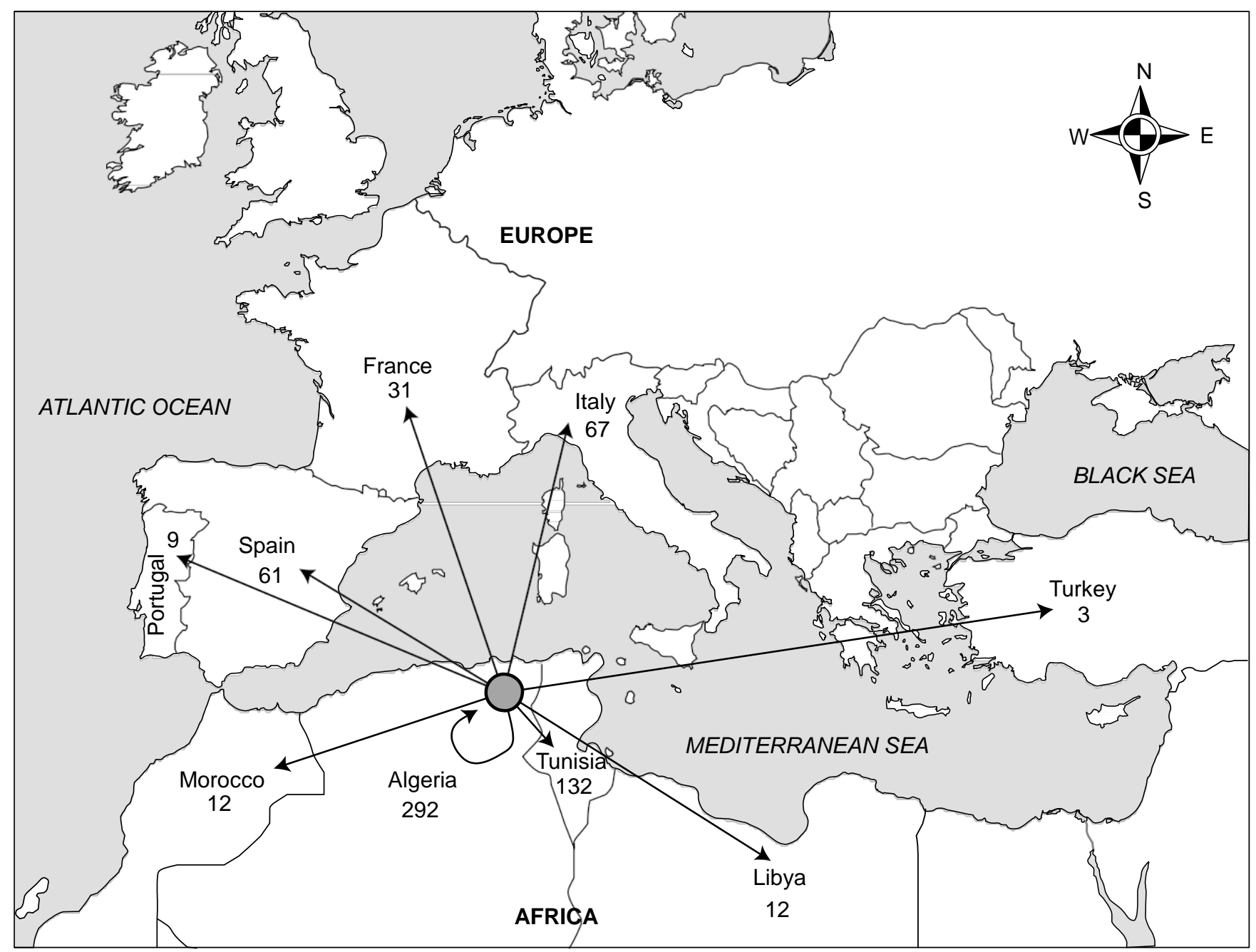

Figure 4: Postfledging dispersal of Greater Flamingos born and ringed at the Garaet Ezzemoul and El Goléa colonies, Algeria (2006-2010). The number of individuals resighted or recovered is indicated for each country (numbers for Italy include birds recorded from continental Italy, Sicily and Sardinia)

of Algeria by older birds is unclear. Dry years might lead experienced individuals to avoid the region. Recent years have experienced favourable rainfall on the Hauts Plateaux. In drier years, older birds may displace younger age-classes to suboptimal habitats (e.g. Sahara or freshwater wetlands) as competition for resources is likely to shape age-structure distributions of flamingos in habitats (Rendón et al. 2001). As the number of older flamingos breeding in Algeria increases, one also might expect a larger number of older individuals to winter in the region.

We provide the first evidence that Greater Flamingos wintering in Algeria come from as far as Turkey. Balkız et al. (2007) suggested that the metapopulation of the Greater Flamingo in the Mediterranean region extends to Turkey, based on records of dispersal from western to eastern colonies but, to confirm that Turkey is a part of the Mediterranean metapopulation, records of natal and breeding dispersals of flamingos born in Turkey were required. The number of Turkish (Gediz delta colony) breeders observed at the Garaet Ezzemoul colony was low. However, when correcting for the proportion that was ringed and the resighting probabilities, we estimated that $1.6 \%$ of breeders at Garaet Ezzemoul in 2009 were from the Gediz delta colony. In contrast, the proportion of breeders at Algerian colonies estimated to be from north-western Mediterranean colonies was high: 100\%, 94\% and 83\% in 2005, 2006 and 2009, respectively, were from France or Spain. This is probably linked to the close proximity of these nations to Algeria.

Resightings of ringed flamingos during the non-breeding period remain limited because of the wide dispersion of birds at that time of the year. Harsh field conditions and poor accessibility of most sites were a major constraint. In addition, most rings (98.9\%) were read in the eastern part of Algeria (Hauts Plateaux and north-eastern Algerian Sahara sites). Further studies should attempt to cover a wider range of Algerian sites.

The limited resighting effort at Garaet Ezzemoul in 2005 possibly led to underestimation of the number of northern Mediterranean breeders there. A higher resighting effort (45 days per week) is needed for the method of Balkı et al. (2007) to be reliable. Nest counts provide an underestimate of the actual number of breeding pairs, as turnover of pairs 
Table 2: Numbers of Greater Flamingos ringed as fledglings in Algeria (2006-2010) and later resighted or recovered in Algeria or other countries

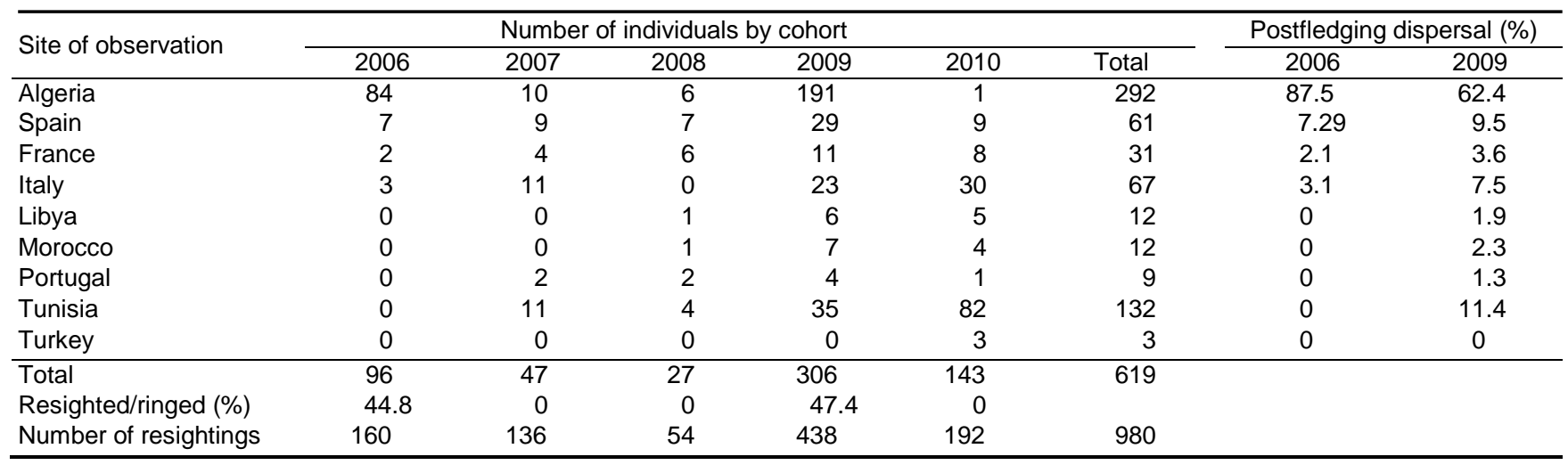

at nests is common in flamingos (Green and Hirons 1988). This likely explains why, in 2009, estimates of the number of breeders originating from north Mediterranean colonies exceeded the number of breeders estimated from nest counts at both Garaet Ezzemoul and El Goléa (Table 2).

Compared to the two saturated colonies at Fuente de Piedra and Camargue, the proportion of young mature Greater Flamingos was higher at the Garaet Ezzemoul colony. This can be explained by competition for food and nesting place, in accordance with the despotic distribution hypothesis (Cooch et al. 1993, Spear et al. 1998, Rendón et al. 2001, Balkız et al. 2010). Noteworthy is the greater number of older breeders at Garaet Ezzemoul in 2009 compared to 2006. This may indicate that Garaet Ezzemoul is becoming a well-established and attractive colony, a possible result of a wetter period. Alternatively, the recent conservation measures aimed at ensuring a protected breeding colony may have reinstated Garaet Ezzemoul to its former status of a reproductive site for Greater Flamingos (Samraoui et al. 2010).

Greater Flamingos ringed as chicks in Algeria exhibited widespread postfledging dispersal that extended as far as Morocco, Libya, Portugal and Turkey. There is even a hint of an exchange with a West African colony (an unconfirmed Algerian ring recorded in Mauritania; B Samraoui unpublished record). Although the resighting rate is not uniform across regions, postfledging dispersal seems to be related to distance.

Acknowledgements - We are grateful to Luc Hoffmann and the Tour du Valat Foundation for material support. This work was financed by the MAVA foundation, the Algerian Ministère de l'Enseignement Supérieur et de la Recherche Scientifique (MESRS/CNEPRU) and DSFP, King Saud University, Saudi Arabia. AB benefited from a PhD thesis grant from the MAVA foundation.

\section{References}

Amat JA, Rendón MA, Rendon-Martos M, Garrido A, Ramirez JM. 2005. Ranging behaviour of Greater Flamingos during the breeding and post-breeding periods: linking connectivity to biological processes. Biological Conservation 125: 183-192.

Balkız Ö, Uygar Ö, Pradel R, Germain C, Siki M, Amat JA, RendónMartos M, Baccetti N, Béchet A. 2007. Range of the Greater
Flamingo Phoenicopterus roseus in the Mediterranean: new insights from Turkey. Journal of Ornithology 148: 347-355.

Balkız Ö, Béchet A, Rouan L, Choquet R, Germain C, Amat JA, Rendón-Martos M, Amat JA, Baccetti N, Nissardi S, Özesmi U, Pradel R. 2010. Experience-dependent natal philopatry of breeding Greater Flamingos. Journal of Animal Ecology 79: 1045-1056.

Baccetti N, Panzarin L, Cianchi F, Puglisi L, Basso M, Arcamone E. 2008. Two new Greater Flamingo (Phoenicopterus roseus) breeding sites in Italy. In Childress B, Arengo F, Bechet A (eds), Flamingo, Bulletin of the IUCN-SSC/Wetlands International Flamingo Specialist Group, No. 16, December 2008. Slimbridge: Wildfowl and Wetlands Trust. pp 24-27.

Boulkhssaïm M, Houhamdi M, Samraoui B. 2006. Status and diurnal behaviour of the Shelduck Tadorna tadorna in the Hauts Plateaux, northeast Algeria. Wildfowl 56: 65-78.

Bouzid A, Yousfi A, Boulkhssaim M, Samraoui B. 2009. Première nidification réussie du Flamant Rose Phoenicopterus roseus dans le Sahara algérien. Alauda 77: 139-143.

Cézilly F, Johnson AR. 1995. Re-mating between and within breeding seasons in the Greater Flamingo. Ibis 137: 543-546.

Cézilly F, Viallefont A, Boy V, Johnson AR. 1996. Annual variation in survival and breeding probability in Greater Flamingos. Ecology 77: 1143-1150.

Childress B. 2005. Flamingo population estimates for Africa and southern Asia. In: Childress B, Béchet A, Arengo F and Jarret N (eds), Flamingo, Bulletin of the IUCNSSC/ Wetlands International Flamingo Specialist Group No. 13, December 2005. Slimbridge: Wildfowl and Wetlands Trust. pp 18-21.

Cooch EG, Jefferies RL, Rockwell RF, Cooke F. 1993. Environmental change and the cost of philopatry - an example in the Lesser Snow Goose. Oecologia 93: 129-138.

Diawara Y, Arnaud A, Araujo A, Béchet A. 2007. Nouvelles données sur la reproduction et l'hivernage des Flamants Roses Phoenicopterus roseus en Mauritanie et confirmation d'échanges avec les populations Méditerranéennes. Ostrich 78: 469-474.

Green RE, Hirons MGJ. 1988. Effects of nest failure and spread of laying on counts of breeding birds. Ornis Scandinavia 19: 76-78. Green RE, Hirons MGJ, Johnson AR. 1989. The origin of long-term cohort differences in the distribution of Greater Flamingos Phoenicopterus ruber roseus in winter. Journal of Animal Ecology 58: 543-555.

Hanski IA, Gilpin ME. 1997. Metapopulation biology: ecology, genetics, and evolution. San Diego: Academic Press.

Isenmann P, Moali A. 2000. Oiseaux d’Algérie. Paris: Société d'Etudes Ornithologiques de France.

Johnson A.R. 1997. Long term studies and conservation of Greater 
Flamingos in the Camargue and Mediterranean. Colonial Waterbirds 20: 306-315.

Johnson A, Cézilly F. 2007. The Greater Flamingo. London: T and AD Poyser.

Khelifa R, Youcefi A, Bouzid A, Boucheker A, Boulkhssaim M, Samraoui B. 2009. A new breeding site for the Greater Flamingo Phoenicopterus roseus in Algeria. In: Childress B, Arengo $\mathrm{F}$ and Béchet A (eds), Flamingo, Bulletin of the IUCNSSC/Wetlands International Flamingo Specialist Group No. 17, December 2009. Slimbridge: Wildfowl and Wetlands Trust. pp 44-47.

Ledant JP, Jacobs JP, Jacobs P, Malher F, Ochando B, Roché J. 1981. Mise à jour de l'avifaune algérienne. Gerfaut 71: 295-398.

Nager RG, Johnson AR, Boy V, Rendón-Martos M, Calderon J, Cézilly F. 1996. Temporal and spatial variation in dispersal of Greater Flamingo (Phoenicopterus ruber roseus). Oecologia 107: 204-211.

McCulloch G, Irvine K. 2004. Breeding of Greater and Lesser Flamingos at Sua Pan, Botswana, 1998-2001. Ostrich 75: 236-242.

Pradel R, Johnson AR, Viallefont A, Nager RG, Cézilly F. 1997. Local recruitment in the Greater Flamingo: a new approach using capture-mark-recapture data. Ecology 78: 1431-1445.

Rendón MA, Garrido A, Ramirez JM, Rendón-Martos M, Amat JA. 2001. Despotic establishment of breeding colonies of Greater Flamingos, Phoenicopterus ruber, in southern Spain. Behavioral Ecology and Sociobiology 50: 55-60.

Saheb M, Boulkhssaïm M, Ouldjaoui A, Houhamdi M, Samraoui B. 2006. Sur la nidification du Flamant Rose Phoenicopterus roseus en 2003 et 2004 en Algérie. Alauda 74: 368-371.

Samraoui B, Samraoui F. 2008. An ornithological survey of the wetlands of Algeria: Important Bird Areas, Ramsar sites and threatened species. Wildfowl 58: 71-98.

Samraoui B, Ouldjaoui A, Boulkhssaïm M, Houhamdi M, Saheb M,
Béchet A. 2006. The first recorded reproduction of the Greater Flamingo Phoenicopterus roseus in Algeria: behavioural and ecological aspects. Ostrich 77: 153-159.

Samraoui B, Boulkhssaïm M, Bouzid A, Bensaci E, Germain C, Béchet A, Samraoui F. 2009. Current research and conservation of the Greater Flamingo Phoenicopterus roseus in Algeria. In: Béchet $A$, Rendón-Martos $M$, Amat JA, Baccetti $N$ and Childress B (eds), Flamingo, Bulletin of the IUCN-SSC/Wetlands International Flamingo Specialist Group, Special Publication 1: Proceedings of the IVth international workshop on the Greater Flamingo in the Mediterranean region and northwest Africa, Antequera, Spain, 5-6 November 2007. Slimbridge: Wildfowl and Wetlands Trust. pp 20-25.

Samraoui F, Boulkhssaïm M, Bouzid A, Baaziz N, Ouldjaoui A, Samraoui B. 2010. La reproduction du Flamant Rose Phoenicopterus roseus en Algérie (2003-2009). Alauda 78: 15-25.

Smart M, Azafzaf H, Dlensi H. 2009. Analysis of the mass of raw data on Greater Flamingos Phoenicopterus roseus on their wintering grounds, particularly in North Africa. In: Béchet A, Rendón-Martos $\mathrm{M}$, Amat J, Baccetti N and Childress B (eds), Flamingo, Bulletin of the IUCNSSC/ Wetlands International Flamingo Specialist Group, Special Publication 1: Proceedings of the IVth international workshop on the Greater Flamingo in the Mediterranean region and northwest Africa, Antequera, Spain, 5-6 November, 2007. Slimbridge: Wildfowl and Wetlands Trust. pp 58-61.

Spear LB, Pyle P, Nur N. 1998. Natal dispersal in the Western Gull: proximal factors and fitness consequences. Journal of Animal Ecology 67: 165-179.

Tavecchia G, Pradel R, Boy V, Johnson AR, Cézilly F. 2001. Sex and age-related variation in survival and cost of first reproduction in Greater Flamingos. Ecology 82: 165-174.

Wetlands International. 2006. Waterbird population estimates (4th edn). Wageningen: Wetlands International. 